\title{
RightS, FightS and PolicieS
}

"Everything under heaven is in utter chaos; the situation is excellent." This phrase is attributed to Mao Zedong and it conjures up a mixture of an apocalypse with a new dawn.

Slavoj Žižek, a social scientist and Slovenian philosopher, recently redeemed and disseminated the phrase in his book "Living in the End Times" published in 2012 by Editora Boitempo, in which the author singles out elements that foretell the final crisis of capitalism: "the ecological crisis, the consequences of the biogenetic revolution, the imbalances of the system itself (intellectual property problems, the upcoming struggle for raw materials, food and water) and the exploding of social divisions and ruptures".

Žižek does not fail, however, to identify emancipatory signs that indicate a new beginning.

The sensation that overwhelms us in Brazil today is one of discouragement at the setback that we are experiencing in terms of the loss of rights acquired during previous struggles. On the other hand, struggle and resistance are part of the DNA of Brazilian Public Health. I would not say that there is a new future approaching on the horizon, but it is an excellent opportunity to review and produce new conceptual experiences and to imagine other possibilities of struggles and resistance.

This thematic issue entitled "Right to the City: Promoting Equity for Vulnerable Groups" strives to contribute to this struggle by putting the city, its vulnerabilities and potential into the limelight.

The 13 articles that open this edition of the Journal problematize the theme and are subdivided into five fronts raising the issues of:

(1) the right to the city and distinct urban agendas - Healthy Cities, Sustainable Cities, Smart Cities and Educational Cities - and their interconnections with the right to health;

(2) ways of listening and participating in groups in a vulnerable situation in the search for the right of minorities to exist and increase their regimes of visibility in coping with the fragilities found in the occupation of urban space, land use, infrastructure, public safety, basic sanitation, etc.;

(3) evaluative methodologies prioritizing not only monitoring the effectiveness of the practices, but also conferring a less fragmented degree to the construct of "vulnerability" from the disciplinary standpoint, without neglecting, however, the territorial specificities of public policies;

(4) the protection afforded by law to minorities, analyzing "legislative vulnerability" as "weak" or "strong" in relation to the elderly, disabled, LGBTs, Indians, women, children/adolescents and afro-descendants;

(5) policies and programs that seek to implement the right to the city emphasizing the necessary intersectoral articulation that creates synergy in the diversity of resources, talents and ideas and that strengthens the approach to social determinants of health.

It is understood that the question of what type of city is desired, cannot be divorced from the type of social bonds, relationships with nature, lifestyles, technologies and aesthetic values.

The British geographer David Harvey introduces this debate with a more connective reflection between citizens, cities, values and nature. For him the right to the city depends on the exercise of a collective power to shape the process of urbanization, since the freedom to build and rebuild the city and ourselves has been one of the most precious and neglected human rights.

The right to health is part of the set of social rights recognized and guaranteed by some countries, which are inspired by the state's duty to finance health actions and universality as a citizen's right.

The right to health intersects with the right to the city to the extent that, by ensuring healthy urban spaces for the population, it will also reduce inequities and enhance the enjoyment of the positive effects of urbanization to excluded and disadvantaged groups

Marco Akerman, Glória Lúcia Alves Figueiredo, Carlos Henrique Gomes Martins Guest Editors 